\title{
Body growth of replacement dairy heifers from 3 distinct genetic groups from commercial Brazilian dairy herds
}

\author{
Marcos Busanello, ${ }^{1 *}$ Debora G. Sousa, ${ }^{1}$ Milaine Poczynek, ${ }^{2}$ Rodrigo de Almeida, ${ }^{2}$ Carla M. M. Bittar, ${ }^{1}$ \\ Filipe A. C. Mendonça, ${ }^{1}$ and Dante P. D. Lanna ${ }^{1}$ \\ ${ }^{1}$ Department of Animal Science, "Luiz de Queiroz" College of Agriculture, University of São Paulo, Piracicaba, São Paulo, 13418-900, Brazil \\ ${ }^{2}$ Department of Animal Science, Federal University of Paraná, Curitiba, Paraná, 80035-050, Brazil
}

\begin{abstract}
Few studies have been published on the body growth of replacement dairy heifers from Jersey (JER) and Holstein $\times$ Gyr $(\mathrm{H} \times \mathrm{G})$ breeds, as most of them have focused on Holstein (HOL) heifers. In addition, HOL genetics vary significantly across countries. Our goal was to study the body growth curves of 3 distinct genetic groups of heifers (HOL, $\mathrm{H} \times \mathrm{G}$, and JER) using data from Brazilian commercial dairy herds. Heart girth [to estimate body weight (BW)], hip height $(\mathrm{HH})$, and withers height $(\mathrm{WH})$ were measured. Weights (heifers and cows) and heights (only heifers) were collected from animals in several herds for each genetic group to model and describe the growth rates, mature body weight (MBW), weights, and heights for the recommended age at first breeding (RAFB) and first calving (RAFC). The RAFB values for HOL, $\mathrm{H} \times \mathrm{G}$, and JER cattle were 15, 18, and 13 mo, respectively. The RAFC values for $\mathrm{HOL}, \mathrm{H} \times \mathrm{G}$, and JER cattle were 24, 27, and 22 mo, respectively. Data were obtained from 18 dairy farms located in 4 Brazilian states and analyzed using nonlinear modeling. Data were collected from 2,266 animals: $878 \mathrm{HOL}, 610 \mathrm{H} \times \mathrm{G}$, and $778 \mathrm{JER}$ cattle. We observed different body growth patterns in each genetic group. Jersey cattle matured earlier than $\mathrm{HOL}$ and $\mathrm{H} \times \mathrm{G}$, especially for BW and $\mathrm{HH}$. Mature BW of the HOL, $\mathrm{H} \times \mathrm{G}$, and JER cattle was 681,607 , and $440 \mathrm{~kg}$, respectively. All genetic groups reached the recommended BW at RAFB. However, the genetic groups did not reach the recommended BW at RAFC. Average daily weight gain from weaning to RAFB was $0.84,0.53$, and $0.54 \mathrm{~kg} / \mathrm{d}$ for $\mathrm{HOL}, \mathrm{H} \times \mathrm{G}$, and JER cattle, respectively. Average daily gain from RAFB to RAFC was $0.53,0.42$, and $0.48 \mathrm{~kg} / \mathrm{d}$ for $\mathrm{HOL}, \mathrm{H} \times \mathrm{G}$,
\end{abstract}

Received August 23, 2021.

Accepted December 13, 2021.

*Corresponding author: marcosbusanello@hotmail.com and JER cattle, respectively. The HH at RAFB and RAFC were 130 and $139 \mathrm{~cm}$ for HOL, 130 and 137 $\mathrm{cm}$ for $\mathrm{H} \times \mathrm{G}$, and 114 and $124 \mathrm{~cm}$ for JER. Withers height at RAFB and RAFC were 125 and $134 \mathrm{~cm}, 125$ and $134 \mathrm{~cm}$, and 110 and $121 \mathrm{~cm}$ for HOL, H $\times \mathrm{G}$, and JER cattle, respectively. In general, the rearing practices were adequate to reach the recommended $\mathrm{BW}$ at RAFB but below the recommended BW at RAFC for all genetic groups. In addition, each genetic group demonstrated different body growth patterns, especially for BW.

Key words: Holstein $\times$ Gyr, structural growth, Jersey, mature body weight

\section{INTRODUCTION}

Rearing dairy heifers is necessary for replacing culled cows and increasing herd size. However, growth rates and the management imposed on heifers can affect their future lactation performance (Zanton and Heinrichs, 2005; Machado et al., 2020). Boulton et al. (2017) suggested that all the costs involved in heifer rearing are typically paid back when they reach 1.5 to 2 lactations. However, only $\sim 55 \%$ of dairy heifers reach the third lactation (Brickell and Wathes, 2011). If we assume 25 mo as mean age at first calving and 64 mo as mean age at culling, a dairy cow remains as a nonproductive individual (calf and heifer) for $39 \%$ of its lifespan. Consequently, the rearing phase plays a significant role in the productive life of dairy heifers.

An important factor related to both the growth and growth rate of dairy heifers is the mature body weight (MBW). Animals with lower MBW tend to have a higher rate of maturation and vice versa (Jenkins et al., 1993). The regular measurement of MBW is not a common practice at dairy farms. However, it is a crucial input for the accurate estimation of the nutritional requirements of growing heifers, and even young cows (NRC, 2001; NASEM, 2021). Some recent studies have described MBW for different dairy cattle genotypes. For example, Berry et al. (2005) evaluated 3 different 
genotypes of Holstein (HOL) cattle and found that they show different MBW, whereas Duplessis et al. (2015) determined MBW for some dairy cattle breeds in Canada.

Currently a common practice at dairy farms is to monitor the growth using the ADG of heifers based on BW until their first calving. However, the most accurate practice to evaluate growth should be the measurement of height growth (from hip and withers height; $\mathbf{H H}$ and $\mathbf{W H}$ ) together with BW. Some studies have been published on the body growth of dairy cattle, especially in Bos taurus cattle, such as HOL (Heinrichs and Hargrove, 1987; Heinrichs and Losinger, 1998; Berry et al., 2005; Duplessis et al., 2015), Jersey (JER), Guernsey (Heinrichs and Hargrove, 1991; Duplessis et al., 2015), Ayrshire, Brown Swiss, and Milking Shorthorn (Heinrichs and Hargrove, 1994; Duplessis et al., 2015). These studies measured the BW and WH. Recent studies have also been conducted on HOL, JER, and Holstein $\times$ Jersey crossbred cattle in New Zealand (Handcock et al., 2019a,b); HOL, JER, Ayrshire, and Brown Swiss cattle in Canada (Duplessis et al., 2015); and HOL cattle in Brazil (Silva et al., 2021).

Therefore, although we have some research in that regard, most of the data are from the United States and from HOL of high genetic merit. In Brazil, crossbred Holstein $\times \operatorname{Gyr}(\mathbf{H} \times \mathbf{G})$ dairy cattle represent $50 \%$ of lactating cows (Martins et al., 2018) and are one of the most important genetic groups, as well as HOL and JER cattle. To date, body growth curves have not been studied for crossbred $\mathrm{H} \times \mathrm{G}$ cattle. Moreover, growth curve data of dairy cattle raised in tropical regions are scarce.

Thus, our objective was to estimate and compare the body growth curves of 3 distinct genetic groups (HOL, $\mathrm{H} \times \mathrm{G}$, and JER) raised in Brazilian conditions using data from commercial dairy farms. We aimed to generate growth curves based on $\mathrm{BW}, \mathrm{HH}$, and $\mathrm{WH}$ for the heifers of these 3 genetic groups. We also aimed to describe the growth rates (ADG), MBW, BW, and heights for the recommended age at first breeding (RAFB) and first calving (RAFC) for each genetic group. We hypothesized that these genetic groups present different body growth patterns.

\section{MATERIALS AND METHODS}

\section{Ethical Statement}

This study was approved by the Animal Care Ethics Committee of the "Luiz de Queiroz" College of Agriculture," University of São Paulo (protocol number 2019-15).

\section{Study Design}

An observational cross-sectional design was employed for this study, in which the cows and heifers were measured only once during the data collection period (from November 2019 to November 2020). We followed the recommendations of the STROBE statement for reporting observational studies (Sargeant and O'Connor, 2014). The dairy farms included in this study were selected using 2 nonprobabilistic sampling methods. First, a quota sampling technique was used, where the dairy farms were classified by characteristics (dairy genetic groups; HOL, $\mathrm{H} \times \mathrm{G}$, or JER), and where $\sim 600$ animals (heifers and cows) were considered to achieve the cattle genetic group quota. Second, a convenience or consecutive sampling, as described in more detail by Martínez-Mesa et al. (2016), was used to select the dairy farms to be included in the study. Dairy farms were consecutively selected according to their accessibility.

\section{Farm Characteristics, Animals, and Data Collection}

Data were collected from 18 dairy farms located in Paraná (PR, $\mathrm{n}=6$ ), São Paulo (SP, $\mathrm{n}=6$ ), Rio Grande do Sul (RS, $\mathrm{n}=5$ ), and Minas Gerais (MG, $\mathrm{n}=1$ ), which are among the main milk-producing regions in Brazil. A total of $6 \mathrm{HOL}, 3 \mathrm{H} \times \mathrm{G}, 6 \mathrm{JER}$, and 3 mixed (with animals of 2 or 3 genetic groups) dairy herds were visited. Confinement ( $\mathrm{n}=13$; freestall or compost barn) was the main production system used for lactating cows, followed by semi-confinement $(\mathrm{n}=5)$.

Heifer rearing systems on farms varied among pasture, semi-confinement, and confinement according to the life stage of the animals. Most of the younger heifers (from 3 to $\sim 12 \mathrm{mo}$ ) were reared in a confinement system ( $\mathrm{n}=11$ farms), whereas the remaining heifers were reared in pasture with some supplementary feed $(\mathrm{n}=7)$. Most of the older heifers (from $\sim 12 \mathrm{mo}$ until first calving) were reared in pasture with some supplementary feed ( $\mathrm{n}=13$ farms), whereas the others were reared exclusively in pasture $(\mathrm{n}=3$ farms $)$ or in confinement systems ( $\mathrm{n}=2$ farms). The feeds used and feed management adopted varied from farm to farm and season. The most commonly used pastures were Brachiaria (syn. Urochloa), Cynodon dactylon, ryegrass (Lolium multiflorum), sorghum (Sorghum bicolor), wheat (Triticum aestivum, especially dual-purpose varieties), and white oats (Avena sativa). The most common conserved forages used as supplementary feed were hay and pre-dried forages (from the above-mentioned pastures and alfalfa, Medicago sativa), as well as corn and oat silage. Furthermore, some commercial concen- 
trates were provided mainly for younger heifers. No specific information about the concentrate composition was provided by farmers.

The daily average milk production of these farms (excluding the mixed ones) was $\sim 28 \mathrm{~kg} /$ cow per day for HOL, $\sim 21 \mathrm{~kg} /$ cow per day for $\mathrm{H} \times \mathrm{G}$, and $\sim 23 \mathrm{~kg} /$ cow per day for JER. The $\mathrm{H} \times \mathrm{G}$ cattle composition was ${ }^{3} /{ }_{4}$ Holstein $\times 1 / 4$ Gyr for most animals $(>80 \%)$, and the remaining $(\sim 20 \%)$ showed genetic compositions such as $1 / 2$ Holstein $\times 1 / 2$ Gyr, $5 / 8$ Holstein $\times 3 / 8$ Gyr (known as Girolando breed), $5 / 8 \mathrm{Gyr} \times 3 / 8$ Holstein, and others. A total of 2,266 animals were measured: $878 \mathrm{HOL}$ (heifers $=490$ and cows $=388$ ), $610 \mathrm{H} \times \mathrm{G}$ (heifers $=440$ and cows $=170$ ), and 778 JER cattle (heifers $=426$ and cows $=352$ ).

Each farm was visited once, and all the animals or a sample of them (when the herd was too large) were measured. This strategy enabled us to visit more dairy farms and measure more animals than measuring the same ones several times during their development to study their growth. The $\mathrm{HH}, \mathrm{WH}$, and heart girth (HG) were measured in heifers from weaning until near the first calving (3-30 mo). For lactating cows, only the HG was measured. A random sample of cows in different lactations was collected. Preference was given to cows in the middle of lactation. Fresh $(<15$ DIM) and dry cows were not measured. Birth dates were provided for all the animals.

We took care to ensure that the animals were standing on a level surface with the correct posture for height measurements. The $\mathrm{HH}$ was measured from the floor to the top of the animal above the ilium bone region using a stick with a metric-scale tape. The WH was measured using the same equipment but above the shoulder blade region of the heifers. The HG was measured with a weight-measuring metric tape (Bovitec) circling the tape behind the animals' front legs. This tape has 3 lines with distinct BW for large (HOL), medium (Guernsey), and small (JER) dairy breeds. Thus, BW was estimated based on the weighing metric tape. Weighing metric tape is one of the most accurate indirect methods for measuring BW in cattle (Dingwell et al., 2006). For $\mathrm{H} \times \mathrm{G}$ animals, an equation based on the HG was used to estimate the BW from the study of Oliveira et al. (2013): BW $(\mathrm{kg})=0.00058 \times \mathrm{HG}^{2.6135}$, where HG is the heart girth in centimeters.

\section{Evaluated Nonlinear Models and Calculations}

There is no consensus on which nonlinear model is the best; generally, it depends on the nature of the research and on what applications results will be used for (Berry et al., 2005). Therefore, 5 nonlinear models were fitted to the data (Table 1): 2 logistic models, in addition to
Von Bertalanffy, Gompertz, and Brody models. All of the models were fitted to the $\mathrm{HH}, \mathrm{WH}$, and $\mathrm{BW}$ data plotted against age in months. Moreover, the random effect of the farm was considered in all models to adjust for factors such as the effects of management, genetics, and other possible factors causing variation among farms. Data on $\mathrm{HH}$ and $\mathrm{WH}$ were modeled up to the age of 30 mo for heifers that had not calved, comprising the recommended age of 22 to 24 mo for average at first calving for European cattle (Van Amburgh and Tikofsky, 2001; Pietersma et al., 2006) plus 6 mo for late puberty genetic groups such as $\mathrm{H} \times \mathrm{G}$ heifers (Facó et al., 2005; McManus et al., 2008; Delgado et al., 2012; Ribeiro et al., 2017; Canaza-Cayo et al., 2018; Azevedo et al., 2020). Body weight data for all cows and heifers were used without an age limit. The best models for each genetic group and variable were selected based on the Akaike and Bayesian information criteria (AIC and $\mathbf{B I C}$, respectively). When models showed very similar AIC and BIC values, the root mean square error and $\mathrm{R}^{2}$ were verified. All fitted models can be verified in Supplemental Tables S1, S2, and S3 (https://mfr .osf.io/render?url=https $\% 3 \mathrm{~A} \% 2 \mathrm{~F} \% 2 \mathrm{Fosf} .10 \% 2 \mathrm{Ff} 6 \mathrm{w} 7 \mathrm{~b}$ \%2Fdownload).

For the ADG calculations, we considered RAFB and RAFC at 15 and 24 mo for HOL (Ettema and Santos, 2004; Do et al., 2013); RAFB and RAFC of 18 and 27 mo for $\mathrm{H} \times \mathrm{G}$ cattle (Azevedo et al., 2020); and RAFB and RAFC of 13 and 22 mo for JER cattle (Hutchison et al., 2017; Handcock et al., 2019a; Boothby et al., $2020)$.

\section{Statistical Analysis}

All statistical analyses were performed using the SAS OnDemand software (SAS Institute Inc., 2015).

Table 1. Nonlinear models fitted to BW $(\mathrm{kg})$, hip height $(\mathrm{cm})$, and withers height $(\mathrm{cm})$ for Holstein, Holstein $\times$ Gyr, and Jersey cattle plotted against age (mo)

\begin{tabular}{ll}
\hline Model & Equation $^{1}$ \\
\hline Logistic I & $y=\left(A /\left(1+B \times e^{(-k \times A g e)}\right)\right)+\delta+\varepsilon$ \\
Logistic II & $y=A \times\left(1+e^{(-k \times A g e)}\right)^{-m}+\delta+\varepsilon$ \\
Von Bertalanffy & $y=A \times\left(1-B \times e^{(-k \times A g e)}\right)^{3}+\delta+\varepsilon$ \\
Gompertz & $y=A \times e^{\left(-B \times e^{(-k \times A g e)}\right)}+\delta+\varepsilon$ \\
Brody & $y=A \times\left(1-B \times e^{(-k \times A g e)}\right)+\delta+\varepsilon$
\end{tabular}

${ }^{1} y=$ hip height, withers height, or BW $(\mathrm{kg}) ; A=$ asymptote (mature BW or height around first calving); $B=$ coefficient of integration, $k=$ maturation rate; $m=$ parameter that shapes the curve; $\delta=$ random effect of dairy farm; and $\varepsilon=$ random error. 
First, descriptive statistics were performed for all the studied variables in general and by genetic groups to verify the biological coherence of the data using the MEANS, FREQ, and REG procedures from SAS. Next, nonlinear models were fitted to the data for $\mathrm{HH}, \mathrm{WH}$, and BW for each genetic group using the NLMIXED procedure from SAS. The normality, homogeneity, and independence of errors for each model were verified. The level of significance was set at a probability of 0.05 .

\section{RESULTS}

Descriptive statistics categorized by genetic group and related to the studied variables are shown in Table 2 .

\section{BW Growth}

The final nonlinear models selected for BW growth were Von Bertalanffy, logistic II, and logistic I for $\mathrm{HOL}, \mathrm{H} \times \mathrm{G}$, and JER genetic groups, respectively.
Coefficient $A$ is related to the asymptote and can be interpreted as MBW. The MBW found were 681, 607, and $440 \mathrm{~kg}$ for HOL, $\mathrm{H} \times \mathrm{G}$, and JER, respectively (Table 3 ). The BW maturity rate (coefficient $K$ ) was higher for JER (0.17) than for HOL (0.09) and $\mathrm{H} \times$ G (0.09), indicating a similar BW growth pattern for HOL and $\mathrm{H} \times \mathrm{G}$ cattle (Table 3 ). The model-predicted and observed values for BW by genetic group are shown in Figure 1. The proportions of MBW at RAFB and RAFC were also calculated. At RAFB, $\mathrm{H} \times \mathrm{G}$ reached $59 \%$ of MBW, whereas HOL and JER reached $58 \%$ and $56 \%$ of MBW, respectively (Table 4). At RAFC, JER reached a higher \%MBW (86\%), whereas HOL and $\mathrm{H} \times \mathrm{G}$ reached $\leq 80 \%$ of MBW (Table 4). The ADG from weaning until RAFB was higher for HOL $(844 \mathrm{~g} / \mathrm{d})$ and similar for $\mathrm{H} \times \mathrm{G}$ and JER (528 and 540 $\mathrm{g} / \mathrm{d}$, respectively; Table 4). The ADG from RAFB until RAFC was also higher for HOL $(534 \mathrm{~g} / \mathrm{d})$, followed by JER (480 g/d; Table 4). The $\mathrm{H} \times \mathrm{G}$ reached a lower ADG in that growth phase (418 g/d; Table 4$)$.

Table 2. Descriptive statistics for variables of BW $(\mathrm{kg})$, heart girth $(\mathrm{cm})$, hip height $(\mathrm{cm})$, withers height $(\mathrm{cm})$, age $(\mathrm{mo})$, and lactation number regarding heifers and cows and categorized by genetic group

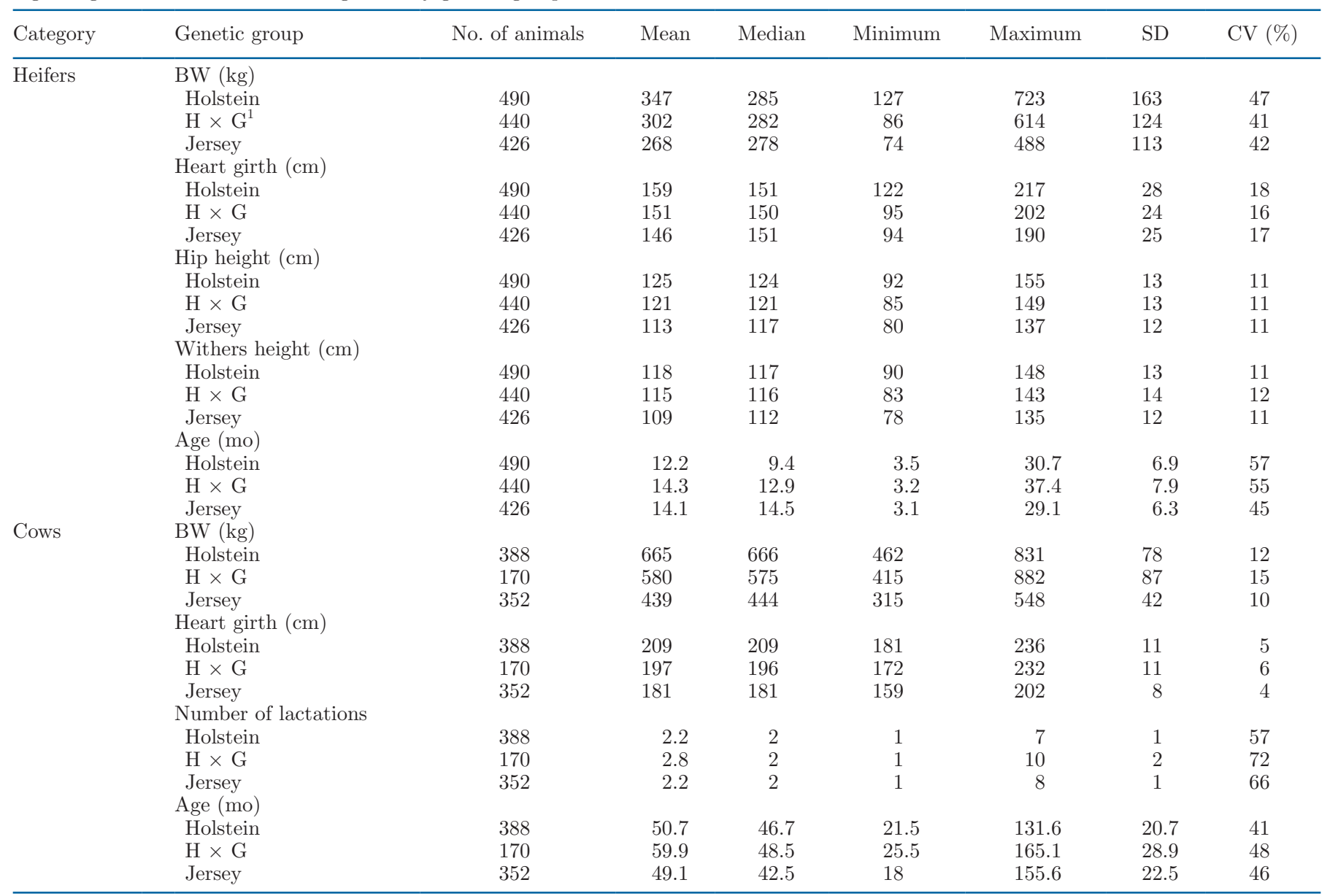

\footnotetext{
${ }^{1}$ Holstein $\times$ Gyr.
} 


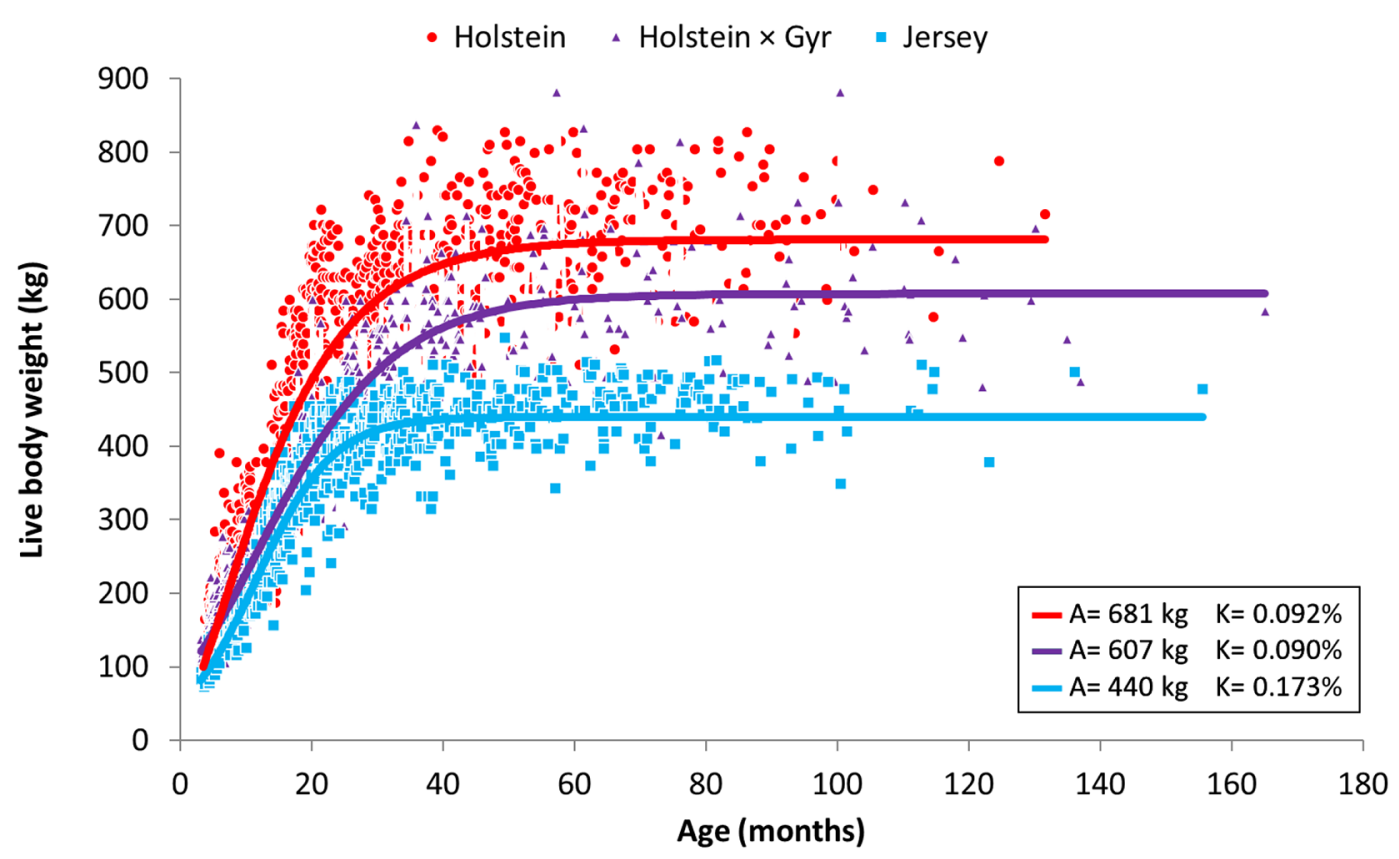

Figure 1. Live BW $(\mathrm{kg})$ growth curves for Holstein, Holstein $\times$ Gyr, and Jersey genetic groups regarding age (mo). Holstein: $y=681.17 \times\left(1-0.6494 \times e^{(-0.09154 \times A g e)}\right)^{3}, \mathrm{R}^{2}=0.8876$, root meansquareerror $(\mathrm{RMSE})=68.974 ;$ Holstein $\times \mathrm{Gyr}: y=607.33 \times\left(1+e^{(-0.08986 \times A g e)}\right)^{-2.8938}$, $\mathrm{R}^{2}=0.9018, \operatorname{RMSE}=53.226$; Jersey: $y=439.88 /\left(1+7.503 \times e^{(-0.1728 \times A g e)}\right), \mathrm{R}^{2}=0.8981, \mathrm{RMSE}=39.172$. Parameter $A$ indicates the mature BW $(\mathrm{kg})$, and parameter $K$ indicates the maturity rate (\%).

\section{Hip Height Growth}

The final nonlinear models selected for $\mathrm{HH}$ growth were Brody for $\mathrm{HOL}$ and $\mathrm{H} \times \mathrm{G}$, and logistic II for JER cattle. Here, coefficient A can be interpreted as $\mathrm{HH}$ at 30 mo of age (the data upper limit; Table 3). The HH maturity rate was higher for JER (0.13) than for HOL (0.09) and $\mathrm{H} \times \mathrm{G}$ (0.09), indicating a similar growth pattern for the HOL and $\mathrm{H} \times \mathrm{G}$ genetic groups (Table 3). The model-predicted and observed values for $\mathrm{HH}$ by genetic group are shown in Figure 2. Hip height was similar at RAFB for HOL and $\mathrm{H} \times \mathrm{G}(130 \mathrm{~cm}$ for both) and lower for JER (114 cm; Table 4). The same occurred at RAFC where HOL and $\mathrm{H} \times \mathrm{G}$ reached a similar HH (139 and $137 \mathrm{~cm}$, respectively), whereas JER reached lower HH (127 cm; Table 4).

Table 3. Nonlinear selected models fitted to BW $(\mathrm{kg})$, hip height $(\mathrm{cm})$, and withers height $(\mathrm{cm})$ for Holstein, Holstein $\times$ Gyr, and Jersey cattle regarding age (mo)

\begin{tabular}{|c|c|c|c|c|c|c|c|c|}
\hline Variable & Cattle & Model & \multicolumn{3}{|c|}{ Parameter $^{1}$} & \multicolumn{3}{|c|}{ Fit statistics ${ }^{2}$} \\
\hline \multirow[t]{2}{*}{ BW (kg) } & Holstein & Von Bertalanffy & 681.17 & 0.6494 & 0.09154 & $9,505.5$ & $9,506.5$ & 0.8876 \\
\hline & Jersey & Logistic I & 439.88 & 7.503 & 0.1728 & $7,669.8$ & $7,670.8$ & 0.8981 \\
\hline \multirow[t]{2}{*}{ Hip height $(\mathrm{cm})$} & Holstein & Brody & 145.47 & 0.4481 & 0.0966 & $2,890.8$ & $2,891.8$ & 0.8185 \\
\hline & Holstein $\times$ Gyr & Brody & 142.31 & 0.4246 & 0.08834 & $2,544.3$ & $2,541.2$ & 0.8564 \\
\hline \multirow{2}{*}{$\begin{array}{l}\text { Withers height } \\
(\mathrm{cm})\end{array}$} & Holstein $\times$ Gyr & Brody & 144.17 & 0.4456 & 0.06769 & $2,529.4$ & $2,526.3$ & 0.8675 \\
\hline & Jersey & Brody & 130.55 & 0.4429 & 0.08142 & $2,320.3$ & $2,320.7$ & 0.8584 \\
\hline
\end{tabular}

${ }^{1} A=$ asymptote; $B=$ integration coefficient; $K=$ rate of maturation.

${ }^{2} \mathrm{AIC}=$ Akaike information criterion; BIC $=$ Bayesian information criterion.

${ }^{3}$ Value of parameter $B$ for all of the models except for logistic II; it is the value of the parameter $m$ of that model. 


\section{Withers Height Growth}

The final nonlinear model selected for WH growth was Brody for all 3 genetic groups. Here, coefficient $A$ can be interpreted as WH at 30 mo of age (the data upper limit; Table 3$)$. Withers height maturity rate was higher for HOL (0.10) and similar for $\mathrm{H} \times \mathrm{G}(0.07)$ and JER (0.08), indicating a higher growth rate for WH in HOL cattle (Table 3). The model-predicted and observed WH values by genetic groups are shown in Figure 3. Withers height was similar at RAFB for HOL and $\mathrm{H} \times \mathrm{G}(125 \mathrm{~cm}$ for both) and lower for JER (110 $\mathrm{cm}$; Table 4). The same occurred at RAFC, where HOL and $\mathrm{H} \times \mathrm{G}$ reached a similar WH (134 $\mathrm{cm}$ for both), whereas JER reached a lower WH (121 cm; Table 4).

\section{DISCUSSION}

The goal of this research was to study the body growth curves of dairy heifers from different genetic groups and to describe the most relevant growth parameters. They can be used to monitor and evaluate the growth targets of heifers in commercial dairy farms. Our results suggest different rates of development with regards to $\mathrm{BW}, \mathrm{HH}$, and $\mathrm{WH}$ among the 3 genetic groups evaluated. It was noticeable that JER cattle had a higher rate of maturation for $\mathrm{BW}$ and $\mathrm{HH}$ compared with $\mathrm{HOL}$ and $\mathrm{H} \times \mathrm{G}$, confirming that the JER breed matures earlier than the other groups (Handcock et al., 2019a). The faster maturation rate can be evidenced by the percentage of MBW (\% MBW) at the same age, as we found that JER presented a higher \%MBW in the same age compared with $\mathrm{HOL}$ and $\mathrm{H} \times \mathrm{G}$ cattle. Animals with higher MBW tend to be less mature at the same age than animals with lower MBW (Fitzhugh and Taylor, 1971). Furthermore, as our results indicate different nonlinear equations for BW for each genetic group, each breed has a specific body growth pattern, as previously demonstrated by Handcock et al. (2019a). Although there are differences in body growth patterns, some studies indicate similar ADG, DMI (Silvestre et al., 2021), and maintenance requirements (Moreira, $2016)$ of $\mathrm{HOL}$ and $\mathrm{H} \times \mathrm{G}\left({ }^{1} / 2\right.$ Gyr $\times 1 / 2$ Holstein $)$ cattle.

Our data for MBW were 681,607 , and $440 \mathrm{~kg}$ for $\mathrm{HOL}, \mathrm{H} \times \mathrm{G}$, and JER, respectively. The MBW of HOL cattle was similar to data from the United States (680 kg, Olson et al., 2010; $682 \mathrm{~kg}$, NRC, 2001) and Israel (687 kg, van Straten et al., 2008). However, the values that we obtained were lower than previous data from Brazil (700 kg, data from a unique confined and high-producing herd, Poncheki et al., 2015) and Austria (734 kg, Ledinek et al., 2019). Furthermore, the values were higher than data from Denmark $(654 \mathrm{~kg}$, Nielsen et al., 2003) and the United Kingdom (668 kg, data including secundiparous cows, Schubert et al., 2019). Additionally, the MBW found for JER cattle was similar to Denmark (448 kg, Nielsen et al., 2003), and lower than data from the United Kingdom $(483 \mathrm{~kg}$, Schubert et al., 2019) and the United States (454 kg, NRC, 2001; $522 \mathrm{~kg}$, Olson et al., 2010). Our results are similar to the NRC (2001) data for HOL, which is consistent with the intensive use of genetic material from the United States in the Brazilian dairy cattle industry, despite the different climatic conditions and production systems.

The MBW found for JER was lower than some estimates found in the literature. A higher ADG of JER before RAFB $(0.54 \mathrm{~kg} / \mathrm{d})$, which was one of our

Table 4. Target BW $(\mathrm{kg})$, ADG $(\mathrm{kg})$, hip height $(\mathrm{cm})$, and withers height $(\mathrm{cm})$ recommended for each genetic group regarding the ages of first breeding and first calving

\begin{tabular}{|c|c|c|c|}
\hline Variable & Holstein & $\mathrm{H} \times \mathrm{G}^{1}$ & Jersey \\
\hline $\mathrm{MBW}(\mathrm{kg})$ & 681 & 607 & 440 \\
\hline \multicolumn{4}{|l|}{ At first breeding ${ }^{2}$} \\
\hline BW (kg) & 397 & 360 & 245 \\
\hline$\% \mathrm{MBW}(\%)$ & 58 & 59 & 56 \\
\hline ADG from weaning to first breeding $(\mathrm{kg} / \mathrm{d})$ & 0.844 & 0.528 & 0.540 \\
\hline $\mathrm{HH}(\mathrm{cm})$ & 130 & 130 & 114 \\
\hline WH $(\mathrm{cm})$ & 125 & 125 & 110 \\
\hline \multicolumn{4}{|l|}{ At first calving ${ }^{3}$} \\
\hline $\mathrm{BW}(\mathrm{kg})$ & 544 & 475 & 377 \\
\hline$\%$ MBW (\%) & 80 & 78 & 86 \\
\hline ADG from first breeding to first calving $(\mathrm{kg} / \mathrm{d})$ & 0.534 & 0.418 & 0.480 \\
\hline $\mathrm{HH}(\mathrm{cm})$ & 139 & 137 & 124 \\
\hline $\mathrm{WH}(\mathrm{cm})$ & 134 & 134 & 121 \\
\hline
\end{tabular}


findings, could reduce their MBW. Average daily gain until puberty can affect the age at puberty. Diets with adequate protein and with no excess energy support structural growth (bone and muscles) and BW of dairy heifers with no change in age at puberty (Moallem et al., 2004). However, high-energy and low-protein diets until puberty can trigger the release of luteinizing hormone, which mediates the entrance to puberty and slows down the lean growth (bone and muscles; Schillo et al., 1992; Moallem et al., 2004). The recommended ages to measure the growth of heifers are especially at birth, at weaning $(\sim 60 \mathrm{~d})$, and near the first breeding (12 to $15 \mathrm{mo}$ ) to monitor ADG (Bazeley et al., 2016).

Compared with JER and HOL cattle, MBW data for $\mathrm{H} \times \mathrm{G}$ cattle are very scarce in the literature, with the exception of $510 \mathrm{~kg}$ for $\mathrm{H} \times \mathrm{G}\left({ }^{1} / 2 \mathrm{Gyr} \times{ }^{1} / 2\right.$ Holstein $)$ cows in the study by Carvalho et al. (2018). This value does not correspond to our finding of $607 \mathrm{~kg}$ of MBW for $\mathrm{H} \times \mathrm{G}$ cattle. It is important to mention that most of the $\mathrm{H} \times \mathrm{G}$ animals in our study were $3 /{ }_{4}$ Holstein $\times$ $1 /{ }_{4} \operatorname{Gyr}(>80 \%)$. This may be the reason why they presented a higher MBW than the animals in the previous study. Based on these results, we can note that MBW is variable among herds and genetic groups. The best practice by dairy farmers should be the measurement of MBW of cows with $\geq 3$ calvings and in the middle of lactation to obtain a reliable estimate of the MBW of their herds.

Mature BW is an important parameter for estimating the nutrient requirements for growing cattle and first- and second-lactation cows for diet formulation. For dairy cattle, growth objectives are based on target weights relative to the MBW (Fox et al., 1999; NRC, 2001; NASEM, 2021). For RAFB, the target weight of a dairy heifer is approximately $55 \%$ of the MBW, whereas for RAFC the target prepartum weight is 91\% of MBW (NASEM, 2021). However, these target weights are based on Bos taurus data (mainly HOL) and consider that dairy heifers reach puberty with 50 to $55 \%$ of MBW (Fox et al., 1999; NRC, 2001; NASEM, 2021). Bos indicus reach puberty with 60 to $65 \%$ of MBW (Patterson et al., 1992). Based on these target weights, ADG can be determined to achieve adequate body growth or according to the breeding goals of the dairy farm. Several studies indicated problems with a high ADG (commonly $>1,000 \mathrm{~g} / \mathrm{d}$, and with highenergy and low-protein diets) before breeding, which could result in fat accumulation in the mammary gland (Sejrsen et al., 1982; Lacasse et al., 1993; Choi et al., 1997; Daniels et al., 2009; Weller et al., 2016). Consequently, the recommended ADG to RAFB is $\sim 800$ $\mathrm{g} / \mathrm{d}$ for HOL heifers, which would not negatively affect

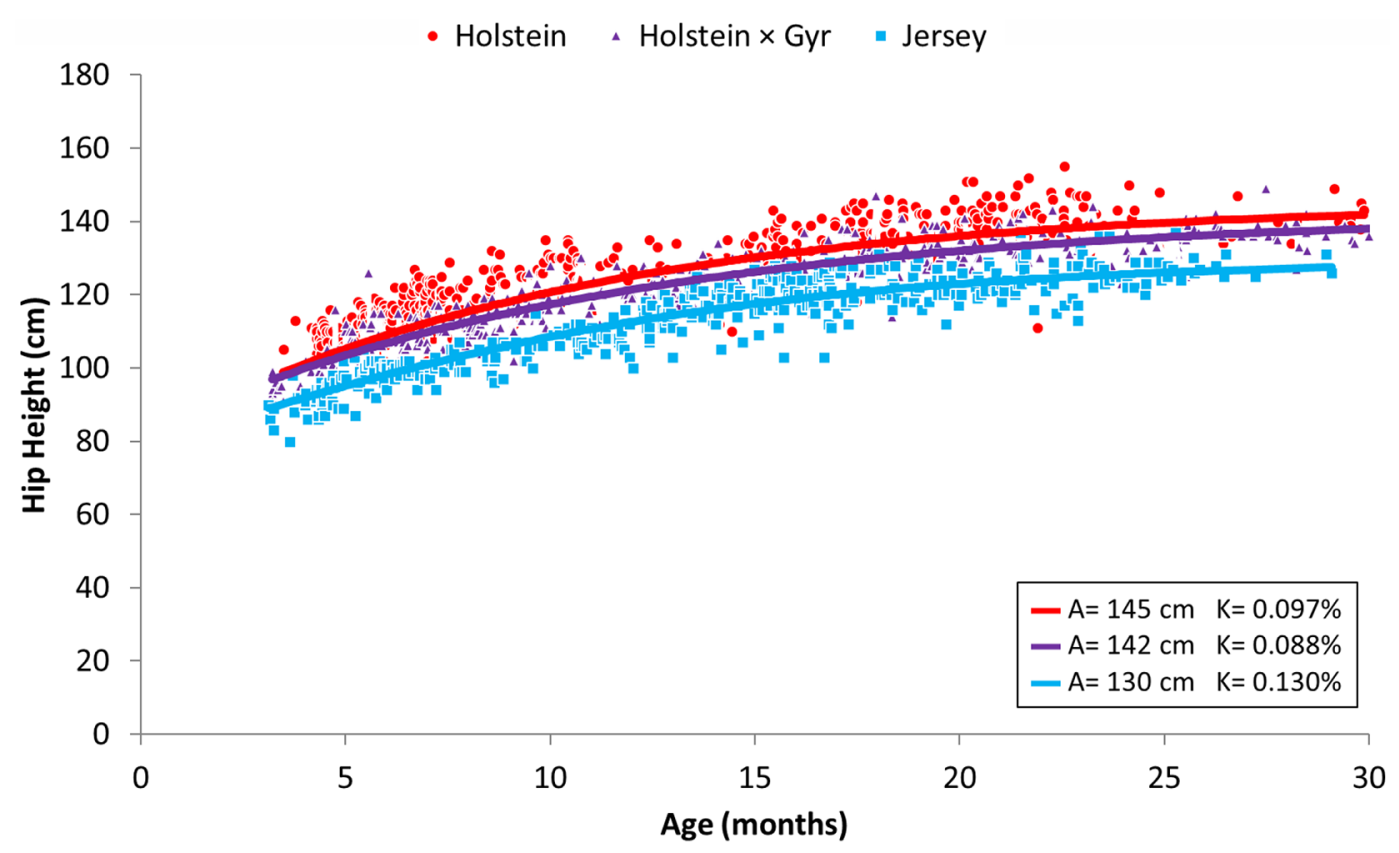

Figure 2. Hip height $(\mathrm{cm})$ growth curves for Holstein, Holstein $\times$ Gyr, and Jersey genetic groups regarding age (mo). Holstein: $y=145.47 \times\left(1-0.4481 \times e^{(-0.0966 \times A g e)}\right), \mathrm{R}^{2}=0.8185$, root mean square error $(\mathrm{RMSE})=5.591 ;$ Holstein $\times$ Gyr: $y=142.31 \times\left(1-0.4246 \times e^{(-0.08834 \times A g e)}\right)$, $\mathrm{R}^{2}=0.8564$, RMSE $=4.921$; Jersey: $y=129.64 \times\left(1+e^{(-0.1297 \times A g e)}\right)^{-0.7365}, \mathrm{R}^{2}=0.8596, \mathrm{RMSE}=4.545$. Parameter $A$ indicates the hip height $(\mathrm{cm})$ at 30 mo of age, and parameter $K$ indicates the maturity rate $(\%)$. 
mammary gland development (Zanton and Heinrichs, 2005) and maximize 305-d milk yield during first lactation. Our finding of $844 \mathrm{~g} / \mathrm{d}$ of ADG for HOL heifers is very close to this recommendation.

For JER heifers, we did not find a reference value for ADG in the literature; however, considering that they should reach $55 \%$ of $\mathrm{MBW}$ at $\mathrm{RAFB}$, our finding of $540 \mathrm{~g} / \mathrm{d}$ is adequate because it resulted in a heifer with $56 \%$ of MBW at 13 mo of age. An ideal ADG to reach $55 \%$ of MBW at first breeding at a different age can be calculated from our predictive equations for each of the genetic groups studied.

In contrast to HOL and JER, $\mathrm{H} \times \mathrm{G}$ cattle still need more studies, as there is a lack of information in the literature regarding the $\% \mathrm{MBW}$ at puberty. It is very difficult to estimate the ideal ADG to reach puberty, and there are almost no data on the effects of ADG on mammary gland development in $\mathrm{H} \times \mathrm{G}$ cattle. Because of the Bos indicus contribution to the genetic composition of this group to different degrees, these animals mature later than HOL and JER and reach puberty later with a higher $\%$ of their MBW. Thus, the rule for $\mathrm{H} \times \mathrm{G}$ heifers is calving at a higher age than $\mathrm{HOL}$ and JER, with studies indicating first calving age at approximately 30 mo (Facó et al., 2005; McManus et al., 2008; Delgado et al., 2012; Ribeiro et al., 2017; Canaza-Cayo et al., 2018; Azevedo et al., 2020). Reduc- ing the age at first calving is a challenge for $\mathrm{H} \times \mathrm{G}$ cattle breeders. However, our results indicate that $\mathrm{H}$ $\times$ G gaining $\sim 530 \mathrm{~g} / \mathrm{d}$ until 18 mo reached $59 \%$ of MBW and, theoretically, could be bred. Improved rearing practices that result in an increase in ADG for $\mathrm{H}$ $\times \mathrm{G}$ until RAFB could reduce the age at first breeding and first calving. Based on our data, $\mathrm{H} \times \mathrm{G}$ are growing adequately to be bred at $\sim 18$ mo of age, resulting in a first calving around the $27 \mathrm{mo}$. In contrast, the calculated ADG from RAFB to RAFC for the 3 genetic groups was lower than the ideal to reach prepartum weights of $91 \%$ of MBW (NASEM, 2021). Jersey cattle were the closest ( $86 \%$ of MBW).

Nevertheless, heifers calving with higher \%MBW produce more milk in first lactation because they present lower nutritional requirements for growth (Handcock et al., 2019b; Van Amburgh et al., 2019). In addition, heifers mobilize fewer reserves in their first lactation than in the following ones (Friggens et al., 2007). However, the relationship between ADG and future milk production depends on the genetic potential of the herd, where breeds with smaller mature size show lower milk yield in response to a higher ADG, especially during the first lactation (Krpálková et al., 2014). It is likely that the effect of fat accumulation in the mammary gland during development is more pronounced in smaller maturesize cattle.

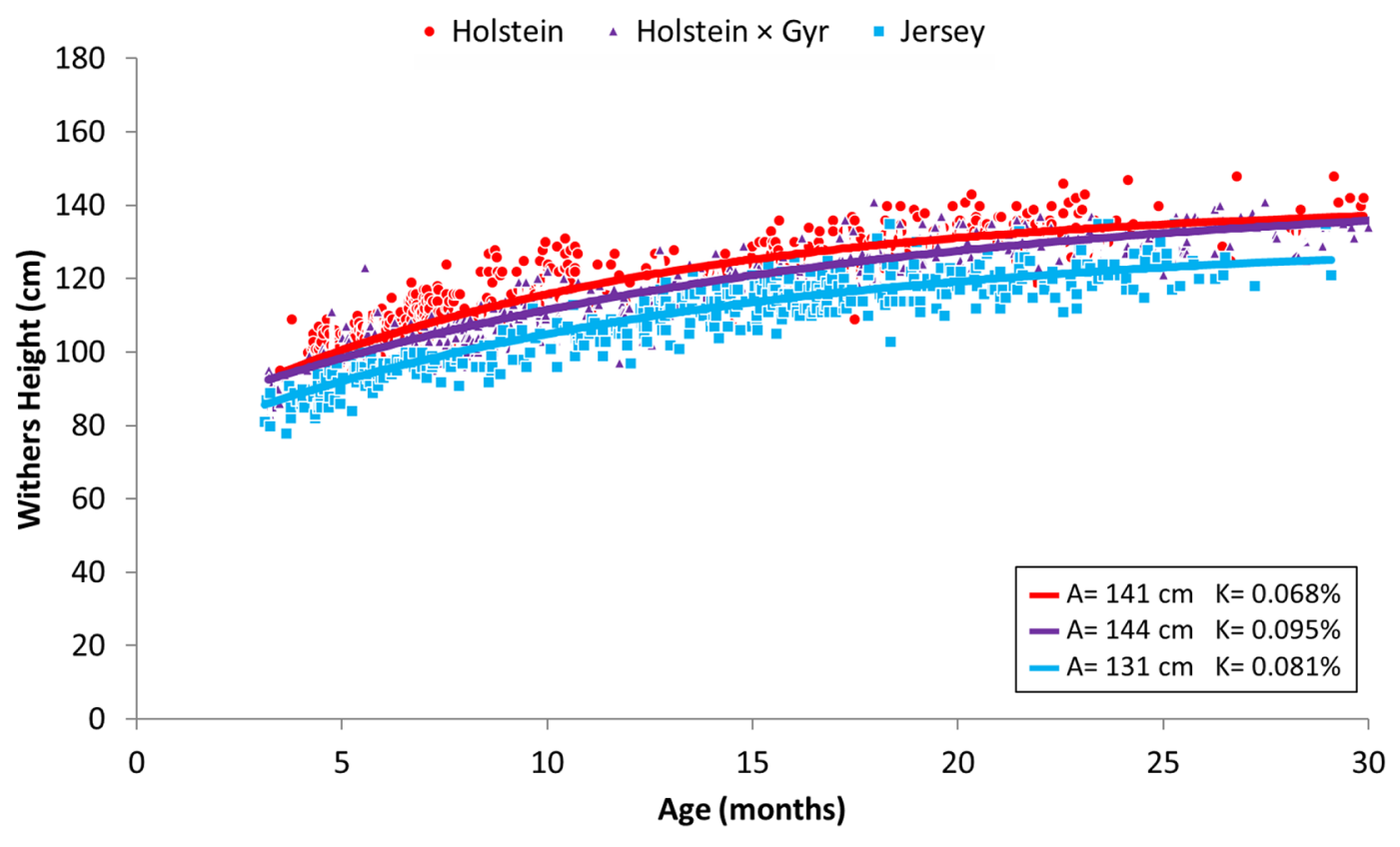

Figure 3. Withers height $(\mathrm{cm})$ growth curves for Holstein, Holstein $\times$ Gyr, and Jersey genetic groups regarding age (mo). Holstein: $y=140.78 \times\left(1-0.46 \times e^{(-0.09512 \times A g e)}\right), \mathrm{R}^{2}=0.8438$, root mean square error $(\mathrm{RMSE})=5.138 ;$ Holstein $\times$ Gyr: $y=144.17 \times\left(1-0.4456 \times e^{(-0.06769 \times A g e)}\right)$, $\mathrm{R}^{2}=0.8675, \mathrm{RMSE}=4.949 ;$ Jersey: $y=130.55 \times\left(1-0.4429 \times e^{(-0.08142 \times A g e)}\right), \mathrm{R}^{2}=0.8596, \mathrm{RMSE}=4.545$. Parameter $A$ indicates the withers height $(\mathrm{cm})$ at $30 \mathrm{mo}$ of age, and parameter $K$ indicates the maturity rate $\%$ ). 
Withers and hip height are well correlated with BW growth (Franco et al., 2017; Silva et al., 2021). Height is not commonly measured in adult animals because $\sim 95 \%$ of mature height is reached at first calving (Heinrichs and Jones, 2016). Very few studies have measured mature WH (Berry et al., 2005; Duplessis et al., 2015; Silva et al., 2021), and to our knowledge, no study has measured HH in dairy cattle. Withers height is more commonly measured than $\mathrm{HH}$, despite $\mathrm{WH}$ being more variable due to the correct position and possible restlessness of the animal at the moment of the measurement. Some WH references for HOL cattle at 15 mo were suggested to be $123 \mathrm{~cm}$ (Heinrichs and Hargrove, 1987); $124 \mathrm{~cm}$ (Heinrichs and Losinger, 1998); $127 \mathrm{~cm}$ (Silva et al., 2021); and $134 \mathrm{~cm}$ (Duplessis et al., 2015). Our results indicate that the sampled Brazilian HOL heifers have an intermediary $\mathrm{WH}$ size at 15 mo (125 $\mathrm{cm}$ ) compared with HOL from other countries. Regarding JER cattle, the values found in the literature for heifers were $108 \mathrm{~cm}$ (at $13 \mathrm{mo}$; Heinrichs and Hargrove, 1991) and $122 \mathrm{~cm}$ (at 15 mo; Duplessis et al., 2015), and our finding of $110 \mathrm{~cm}$ (at $13 \mathrm{mo}$ ) can be indicative of medium to small WH size, compared with JER from other countries. Again, for $\mathrm{H} \times \mathrm{G}$ cattle, we did not find values in the literature for $\mathrm{WH}$.

The HH could be a better measurement of body size than $\mathrm{WH}$ due to a lower variation in the measurement among animals, despite the coefficients of variation being similar for those variables in our data. Heinrichs and Hargrove (1987) found that taller heifers, considering WH at breeding, presented higher milk production in first lactation. Taller animals can also be heavier animals because of the high and positive relationship between weight and height. Although heavier cows can be slightly more profitable than lighter cows, very heavy cows increase feeding costs. This means that it is ideal to maintain an intermediary mature BW in the selection criteria for each farm (Pérez-Cabal et al., 2006). In addition, heavier cows are more prone to have a higher incidence of metabolic disorders and infectious diseases around parturition (Williams et al., 2009; Roche et al., 2013), which increases the culling risk (Chiumia et al., 2013).

Few studies on dairy heifers, particularly JER cattle, are included in the dairy NRC (2001) publication. The recent document published by NASEM (2021) also, practically, does not include heifer data from genetic groups other than HOL. However, in recent years, studies on $\mathrm{H} \times \mathrm{G}$ heifers have been published regarding DMI (Oliveira and Ferreira, 2016; Busanello et al., 2021), growth requirements (Castro et al., 2020), and mammary gland development (Albino et al., 2017; Silva et al., 2018). In addition, recent research on HOL cattle can be found in terms of DMI (Hoffman et al., 2008), growth requirements (Albino et al., 2015; Jiao et al., 2015), and body growth (Heinrichs et al., 2017; Silva et al., 2021). Few studies have been conducted on JER cattle for growth curves and target $\mathrm{BW}$ and $\mathrm{WH}$ along with their growth (Duplessis et al., 2015; Handcock et al., 2019a). It is evident that more research focused on rearing dairy heifers is needed, especially for genetic groups other than HOL cattle, which have received the most attention from researchers.

Finally, our study has some limitations that should be addressed in future research. We chose to sample each animal only once on each farm, increasing the number of measured animals and farms, but others opted to monitor the same animals along with their growth (Berry et al., 2005). It is difficult to decide which would be the most appropriate approach. In our study, we measured more animals, but the growth curve of the same animal is not known. Thus, our growth curve represents the growth curve of the farms' heifers. In this way, our data set contained only repeated measures for dairy farms and not for animals, which resulted in only one additional effect to be modeled on the nonlinear models. This results in a simpler model. This effect was estimated to be random because repeated measure analysis still had limitations when performed on nonlinear models, as in the case of SAS NLIN and NLMIXED procedures. Furthermore, the number of DIM and milk yield of the cows were not recorded, even though DIM has a well-known effect on the BW of lactating cows (van Straten et al., 2008; Poncheki et al., 2015). However, nonlinear models (SAS NLIN and NLMIXED) do not allow the inclusion of covariates in the model. Moreover, part of the weight of pregnant cows and heifers is due to the conceptus and other tissues related to pregnancy, but no adjustments were made considering the conceptus weight in our data. However, we believe that our data adequately represent our tropical and subtropical rearing conditions and genetics because different farms and regions were sampled. However, some sources of bias present on each farm, such as genetics, management, nutrition, and others, are difficult to control because the heifer rearing system changes according to age within farms, and we measured each one in a specific period of their growth.

\section{CONCLUSIONS}

We demonstrated different body growth patterns for each genetic group studied, especially for BW. Adequate ADG is reached from weaning until RAFB; however, from RAFB until RAFC, the ADG is below the ideal for all 3 genetic groups. Height measurements (withers and hip), together with BW, are strongly recommended to evaluate heifers' body growth throughout their life. 


\section{ACKNOWLEDGMENTS}

This study was financed in part by the Brazilian Coordination for the Improvement of Higher Education Personnel (CAPES, Brasília)-Finance Code 001. We are also grateful to the São Paulo Research Foundation (FAPESP), São Paulo, Brazil, for the partial research funding and scholarships to Marcos Busanello (FAPESP Process 2019/02307-2), and to the CNPq fellowship to Dante Pazzanese Duarte Lanna for research productivity level II-B. The authors have not stated any conflicts of interest.

\section{REFERENCES}

Albino, R. L., M. I. Marcondes, R. M. Akers, E. Detmann, B. C. Carvalho, and T. E. Silva. 2015. Mammary gland development of dairy heifers fed diets containing increasing levels of metabolisable protein:metabolisable energy. J. Dairy Res. 82:113-120. https:// doi.org/10.1017/S0022029914000697.

Albino, R. L., A. L. Sguizzato, K. M. Daniels, M. S. Duarte, M. M. Lopes, S. E. F. Guimarães, M. M. D. C. A. Weller, and M. I. Marcondes. 2017. Performance strategies affect mammary gland development in prepubertal heifers. J. Dairy Sci. 100:8033-8042. https://doi.org/10.3168/jds.2016-12489.

Azevedo, R. A., A. M. Teixeira, C. M. M. Bittar, L. F. Martins, L. C. M. S. Antunes, J. A. Zambrano, J. E. P. Santos, P. M. Tiveron, P. P. Rotta, R. M. Meneses, R. O. S. Silva, S. G. Coelho, and V. Gomes. 2020. Alta Cria. https://doi.org/10.26626/978-65-5668 -018-7.2020B0001.

Bazeley, K. J., D. C. Barrett, P. D. Williams, and K. K. Reyher. 2016. Measuring the growth rate of UK dairy heifers to improve future productivity. Vet. J. 212:9-14. https://doi.org/10.1016/j.tvjl.2015 .10 .043 .

Berry, D. P., B. Horan, and P. Dillon. 2005. Comparison of growth curves of three strains of female dairy cattle. Anim. Sci. 80:151160. https://doi.org/10.1079/ASC41790151.

Boothby, F., D. Grove-White, G. Oikonomou, and J. W. H. Oultram. 2020. Age at first calving in UK Jersey cattle and its associations with first lactation 305-day milk yield, lifetime daily milk yield, calving interval and survival to second lactation. Vet. Rec. 187:491. https://doi.org/10.1136/vr.105993.

Boulton, A. C., J. Rushton, and D. C. Wathes. 2017. An empirical analysis of the cost of rearing dairy heifers from birth to first calving and the time taken to repay these costs. Animal 11:1372-1380. https://doi.org/10.1017/S1751731117000064.

Brickell, J. S., and D. C. Wathes. 2011. A descriptive study of the survival of Holstein-Friesian heifers through to third calving on English dairy farms. J. Dairy Sci. 94:1831-1838. https://doi.org/ 10.3168/jds.2010-3710.

Busanello, M., D. G. Sousa, F. A. C. Mendonça, V. L. Daley, R. Almeida, C. M. M. Bittar, and D. P. D. Lanna. 2021. Feed intake of growing dairy heifers raised under tropical conditions: A model evaluation using meta-analysis. Animals (Basel) 11:3181. https:// doi.org/10.3390/ani11113181.

Canaza-Cayo, A. W., P. S. Lopes, J. A. Cobuci, M. F. Martins, and M. V. G. B. Silva. 2018. Genetic parameters of milk production and reproduction traits of Girolando cattle in Brazil. Ital. J. Anim. Sci. 17:22-30. https://doi.org/10.1080/1828051X.2017.1335180.

Carvalho, P. H. A., A. L. C. C. Borges, R. R. Silva, H. F. Lage, P. A. D. Vivenza, J. R. M. Ruas, E. J. Facury Filho, R. L. A. Palhano, L. C. Gonçalves, I. Borges, E. O. S. Saliba, D. G. Jayme, and A. Ú. Carvalho. 2018. Energy metabolism and partition of lactating Zebu and crossbred Zebu cows in different planes of nutrition. PLoS One 13:e0202088. https://doi.org/10.1371/journal.pone .0202088 .
Castro, M. M. D., R. L. Albino, J. P. P. Rodrigues, A. L. L. Sguizzato, M. M. F. Santos, P. P. Rotta, J. S. Caton, L. E. F. D. Moraes, F. F. Silva, and M. I. Marcondes. 2020. Energy and protein requirements of Holstein $\times$ Gyr crossbred heifers. Animal 14:1857-1866. https://doi.org/10.1017/S1751731120000622.

Chiumia, D., M. G. G. Chagunda, A. I. Macrae, and D. J. Roberts. 2013. Predisposing factors for involuntary culling in Holstein-Friesian dairy cows. J. Dairy Res. 80:45-50. https://doi.org/10.1017/ S002202991200060X.

Choi, Y. J., I. K. Han, J. H. Woo, H. J. Lee, K. Jang, K. H. Myung, and Y. S. Kim. 1997. Compensatory growth in dairy heifers: The effect of a compensatory growth pattern on growth rate and lactation performance. J. Dairy Sci. 80:519-524. https://doi.org/10 .3168/jds.S0022-0302(97)75965-4.

Daniels, K. M., M. L. McGilliard, M. J. Meyer, M. E. Van Amburgh, A. V. Capuco, and R. M. Akers. 2009. Effects of body weight and nutrition on histological mammary development in Holstein heifers. J. Dairy Sci. 92:499-505. https://doi.org/10.3168/jds.2008 $-1007$.

Delgado, P. A. M., L. G. R. Calderón, A. M. Aldana, and C. E. L. Penagos. 2012. Desempeño productivo y reproductivo de vacas $F_{1}$ Holstein $\times$ Gyr en clima cálido colombiano. Vet. Zootec. 6:17-23.

Dingwell, R. T., M. M. Wallace, C. J. McLaren, C. F. Leslie, and K. E. Leslie. 2006. An Evaluation of two indirect methods of estimating body weight in Holstein calves and heifers. J. Dairy Sci. 89:39923998. https://doi.org/10.3168/jds.S0022-0302(06)72442-0.

Do, C., N. Wasana, K. Cho, Y. Choi, T. Choi, B. Park, and D. Lee. 2013. The effect of age at first calving and calving interval on productive life and lifetime profit in Korean Holsteins. Asian-Australas. J. Anim. Sci. 26:1511-1517. https://doi.org/10.5713/ajas .2013 .13105

Duplessis, M., R. I. Cue, D. E. Santschi, D. M. Lefebvre, and R. Lacroix. 2015. Weight, height, and relative-reliability indicators as a management tool for reducing age at first breeding and calving of dairy heifers. J. Dairy Sci. 98:2063-2073. https://doi.org/10.3168/ jds.2014-8279.

Ettema, J. F., and J. E. P. Santos. 2004. Impact of age at calving on lactation, reproduction, health, and income in first-parity Holsteins on commercial farms. J. Dairy Sci. 87:2730-2742. https:// doi.org/10.3168/jds.S0022-0302(04)73400-1.

Facó, O., R. N. B. Lôbo, R. Martins Filho, and F. A. M. Lima. 2005 Idade ao primeiro parto e intervalo de partos de cinco grupos genéticos Holandês x Gir no Brasil (Age at first calving and calving interval of five Holstein x Gir genetic groups in Brazil). R. Bras. Zootec. 34:1920-1926. https://doi.org/10.1590/S1516 -35982005000600016 .

Fitzhugh, H. A. Jr., and S. C. S. Taylor. 1971. Genetic analysis of degree of maturity. J. Anim. Sci. 33:717-725. https://doi.org/10 $.2527 /$ jas 1971.334717x.

Fox, D. G., M. E. Van Amburgh, and T. P. Tylutki. 1999. Predicting requirements for growth, maturity, and body reserves in dairy cattle. J. Dairy Sci. 82:1968-1977. https://doi.org/10.3168/jds.S0022 -0302(99)75433-0.

Franco, M. O., M. I. Marcondes, J. M. S. Campos, D. R. Freitas, E. Detmann, and S. C. Valadares Filho. 2017. Evaluation of body weight prediction equations in growing heifers. Acta Sci. Anim. Sci. 39:201-206. https://doi.org/10.4025/actascianimsci.v39i2 .33118 .

Friggens, N. C., P. Berg, P. Theilgaard, I. R. Korsgaard, K. L. Ingvartsen, P. Løvendahl, and J. Jensen. 2007. Breed and parity effects on energy balance profiles through lactation: Evidence of genetically driven body energy change. J. Dairy Sci. 90:5291-5305. https: //doi.org/10.3168/jds.2007-0173.

Handcock, R. C., N. Lopez-Villalobos, L. R. McNaughton, P. J. Back, G. R. Edwards, and R. E. Hickson. 2019a. Live weight and growth of Holstein-Friesian, Jersey and crossbred dairy heifers in New Zealand. N. Z. J. Agric. Res. 62:173-183. https://doi.org/10.1080/ 00288233.2018.1465984.

Handcock, R. C., N. Lopez-Villalobos, L. R. McNaughton, P. J. Back, G. R. Edwards, and R. E. Hickson. 2019b. Positive relationships 
between body weight of dairy heifers and their first-lactation and accumulated three-parity lactation production. J. Dairy Sci. 102:4577-4589. https://doi.org/10.3168/jds.2018-15229.

Heinrichs, A. J., and G. L. Hargrove. 1987. Standards of weight and height for Holstein heifers. J. Dairy Sci. 70:653-660. https://doi .org/10.3168/jds.S0022-0302(87)80055-3.

Heinrichs, A. J., and G. L. Hargrove. 1991. Standards of weight and height for Guernsey and Jersey heifers. J. Dairy Sci. 74:1684-1689. https://doi.org/10.3168/jds.S0022-0302(91)78331-8.

Heinrichs, A. J., and G. L. Hargrove. 1994. Standards of weight and height for Ayrshire, Brown Swiss, and Milking Shorthorn heifers. J. Dairy Sci. 77:1676-1681. https://doi.org/10.3168/jds.S0022 -0302(94)77109-5.

Heinrichs, A. J., B. S. Heinrichs, C. M. Jones, P. S. Erickson, K. F. Kalscheur, T. D. Nennich, B. J. Heins, and F. C. Cardoso. 2017. Short communication: Verifying Holstein heifer heart girth to body weight prediction equations. J. Dairy Sci. 100:8451-8454. https:// doi.org/10.3168/jds.2016-12496.

Heinrichs, A. J., and C. M. Jones. 2016. Monitoring dairy heifer growth. PennState Extension. Penn State College of Agricultural Sciences.

Heinrichs, A. J., and W. C. Losinger. 1998. Growth of Holstein dairy heifers in the United States. J. Anim. Sci. 76:1254-1260. https:// doi.org/10.2527/1998.7651254x.

Hoffman, P. C., K. A. Weigel, and R. M. Wernberg. 2008. Evaluation of equations to predict dry matter intake of dairy heifers. J. Dairy Sci. 91:3699-3709. https://doi.org/10.3168/jds.2007-0644.

Hutchison, J. L., P. M. VanRaden, D. J. Null, J. B. Cole, and D. M. Bickhart. 2017. Genomic evaluation of age at first calving. J. Dairy Sci. 100:6853-6861. https://doi.org/10.3168/jds.2016-12060.

Jenkins, T. G., M. Kaps, L. V. Cundiff, and C. L. Ferrell. 1993. Estimates of mature weights and maturing rates for breed crosses. Beef Research Program Progress Report, No. 4, Part 2. https:// digitalcommons.unl.edu/hruskareports/331/.

Jiao, H. P., T. Yan, D. A. Wills, and D. A. McDowell. 2015. Maintenance energy requirements of young Holstein cattle from calorimetric measurements at $6,12,18$, and 22 months of age. Livest. Sci. 178:150-157. https://doi.org/10.1016/j.livsci.2015.05.031.

Krpálková, L., V. E. Cabrera, J. Kvapilík, J. Burdych, and P. Crump. 2014. Associations between age at first calving, rearing average daily weight gain, herd milk yield and dairy herd production, reproduction, and profitability. J. Dairy Sci. 97:6573-6582. https:// doi.org/10.3168/jds.2013-7497.

Lacasse, P., E. Block, L. A. Guilbault, and D. Petitclerc. 1993. Effect of plane of nutrition of dairy heifers before and during gestation on milk production, reproduction, and health. J. Dairy Sci. 76:34203427. https://doi.org/10.3168/jds.S0022-0302(93)77680-8.

Ledinek, M., L. Gruber, F. Steininger, K. Zottl, M. Royer, K. Krimberger, M. Mayerhofer, C. Egger-Danner, and B. Fuerst-Waltl. 2019. Analysis of lactating cows in commercial Austrian dairy farms: Diet composition, and influence of genotype, parity and stage of lactation on nutrient in-take, body weight and body condition score. Ital. J. Anim. Sci. 18:202-214. https://doi.org/10.1080/ 1828051X.2018.1504632.

Machado, A. F., S. E. F. Guimarães, J. D. Guimarães, G. M. Santos, A. L. Silva, Y. F. R. S. Silva, D. S. Lollobrigida Netto, P. V. F. Correa, and M. I. Marcondes. 2020. Effect of protein supplement level on the productive and reproductive parameters of replacement heifers managed in intensive grazing systems. PLoS One 15:e0239786. https://doi.org/10.1371/journal.pone.0239786.

Martínez-Mesa, J., D. A. González-Chica, R. P. Duquia, R. R. Bonamigo, and J. L. Bastos. 2016. Sampling: How to select participants in my research study? An. Bras. Dermatol. 91:326-330. https://doi.org/10.1590/abd1806-4841.20165254.

Martins, C. M., R. Zoccal, N. Rentero, and A. Albuquerque. 2018. Indicadores, tendências e oportunidades para quem vive no setor leiteiro. Anuário leite 2018. Embrapa Gado de Leite.

McManus, C., R. A. Teixeira, L. T. Dias, H. Louvandini, and E. M. B. Oliveira. 2008. Production and reproduction traits in Holstein and Gyr crossbred cows in the Central Plateau, Brazil. R. Bras. Zootec. 37:819-823. https://doi.org/10.1590/S1516-35982008000500006.
Moallem, U., G. E. Dahl, E. K. Duffey, A. V. Capuco, and R. A. Erdman. 2004. Bovine somatotropin and rumen-undegradable protein effects on skeletal growth in prepubertal dairy heifers. J. Dairy Sci. 87:3881-3888. https://doi.org/10.3168/jds.S0022-0302(04)73527 -4 .

Moreira, T. S. 2016. Energy requirements, energetic partition and methane emission from growing Holstein, Gyr and $F_{1}$ HolsteinGyr dairy heifers. Doctoral thesis, University of São Paulo, Pirassununga, SP, Brazil.

NASEM (National Academies of Sciences, Engineering, and Medicine). 2021. Nutrient Requirements of Dairy Cattle. 8th rev. ed. The National Academies Press.

Nielsen, H. M., N. C. Friggens, P. Løvendahl, J. Jensen, and K. L. Ingvartsen. 2003. Influence of breed, parity, and stage of lactation on lactational performance and relationship between body fatness and liveweight. Livest. Prod. Sci. 79:119-133. https://doi.org/10 .1016/S0301-6226(02)00146-X.

NRC (National Research Council). 2001. Nutrient Requirements of Dairy Cattle. 7th ed. National Academy Press.

Oliveira, A. S., D. C. Abreu, M. A. Fonseca, and P. M. B. Antoniassi. 2013. Short communication: Development and evaluation of predictive models of body weight for crossbred Holstein-Zebu dairy heifers. J. Dairy Sci. 96:6697-6702. https://doi.org/10.3168/jds 2013-6988.

Oliveira, A. S., and V. B. Ferreira. 2016. Prediction of intake in growing dairy heifers under tropical conditions. J. Dairy Sci. 99:11031110. https://doi.org/10.3168/jds.2015-9638.

Olson, K. M., B. G. Cassell, and M. D. Hanigan. 2010. Energy balance in first-lactation Holstein, Jersey, and reciprocal $\mathrm{F}_{1}$ crossbred cows in a planned crossbreeding experiment. J. Dairy Sci. 93:4374-4385. https://doi.org/10.3168/jds.2010-3195.

Patterson, D. J., R. C. Perry, G. H. Kiracofe, R. A. Bellows, R. B. Staigmiller, and L. R. Corah. 1992. Management considerations in heifer development and puberty. J. Anim. Sci. 70:4018-4035. https://doi.org/10.2527/1992.70124018x.

Pérez-Cabal, M. A., C. García, O. González-Recio, and R. Alenda. 2006. Genetic and phenotypic relationships among locomotion type traits, profit, production, longevity, and fertility in Spanish dairy cows. J. Dairy Sci. 89:1776-1783. https://doi.org/10.3168/ jds.S0022-0302(06)72246-9.

Pietersma, D., R. Lacroix, D. Lefebvre, R. I. Cue, and K. M. Wade. 2006. Trends in growth and age at first calving for Holstein and Ayrshire heifers in Quebec. Can. J. Anim. Sci. 86:325-336. https:/ /doi.org/10.4141/A05-080.

Poncheki, J. K., M. L. S. Canha, S. L. Viechnieski, and R. Almeida. 2015. Analysis of daily body weight of dairy cows in early lactation and associations with productive and reproductive performance. R. Bras. Zootec. 44:187-192. https://doi.org/10.1590/S1806 -92902015000500004 .

Ribeiro, L. S., T. J. F. Goes, R. A. Torres Filho, C. V. Araújo, R. B. Reis, and H. M. Saturnino. 2017. Desempenhos produtivo e reprodutivo de um rebanho $\mathrm{F}_{1}$ Holandês x Gir em Minas Gerais. R. Bras. Zootec. 69:1624-1634. https://doi.org/10.1590/1678-4162 -9076 .

Roche, J. R., J. K. Kay, N. C. Friggens, J. J. Loor, and D. P. Berry. 2013. Assessing and managing body condition score for the prevention of metabolic disease in dairy cows. Vet. Clin. North Am. Food Anim. Pract. 29:323-336. https://doi.org/10.1016/j.cvfa.2013.03 .003 .

Sargeant, J. M., and A. M. O'Connor. 2014. Issues of reporting in observational studies in veterinary medicine. Prev. Vet. Med. 113:323-330. https://doi.org/10.1016/j.prevetmed.2013.09.004.

SAS Institute Inc. 2015. SAS ${ }^{\circledR}$ OnDemand for Academics: User's Guide. SAS Institute Inc. https://odamid-usw2.oda.sas.com/ SASStudio/.

Schillo, K. K., J. B. Hall, and S. M. Hileman. 1992. Effects of nutrition and season on the onset of puberty in the beef heifer. J. Anim. Sci. 70:3994-4005. https://doi.org/10.2527/1992.70123994x.

Schubert, H., S. Wood, K. K. Reyher, and H. L. Mills. 2019. Data-driven approach to using individual cattle weights to estimate mean 
adult dairy cattle weight. Vet. Rec. 185:540. https://doi.org/10 $.1136 /$ vr. 105471 .

Sejrsen, K., J. T. Huber, H. A. Tucker, and R. M. Akers. 1982. Influence of nutrition of mammary development in pre- and postpubertal heifers. J. Dairy Sci. 65:793-800. https://doi.org/10.3168/jds .S0022-0302(82)82268-6.

Silva, A. L., E. Detmann, J. Dijkstra, A. M. Pedroso, L. H. P. Silva, A. F. Machado, F. C. Sousa, G. B. dos Santos, and M. I. Marcondes. 2018. Effects of rumen-undegradable protein on intake, performance, and mammary gland development in prepubertal and pubertal dairy heifers. J. Dairy Sci. 101:5991-6001. https:// doi.org/10.3168/jds.2017-13230.

Silva, A. L., T. J. DeVries, E. C. Fernandes, and M. I. Marcondes. 2021. Short communication: Development and evaluation of equations to predict growth of Holstein dairy heifers in a tropical climate. J. Dairy Sci. 104:525-531. https://doi.org/10.3168/jds.2020 -18624 .

Silvestre, T., M. A. Lima, G. B. Santos, L. G. R. Pereira, F. S. Machado, T. R. Tomich, M. M. Campos, A. Jonker, P. H. M. Rodrigues, V. L. N. Brandão, and M. I. Marcondes. 2021. Effects of feeding level and breed composition on intake, digestibility, and methane emissions of dairy heifers. Animals (Basel) 11:586. https://doi .org/10.3390/ani11030586.

Van Amburgh, M. E., F. Soberon, M. J. Meyer, and R. A. Molano. 2019. Symposium review: Integration of postweaning nutrient re- quirements and supply with composition of growth and mammary development in modern dairy heifers. J. Dairy Sci. 102:3692-3705. https://doi.org/10.3168/jds.2018-15270.

Van Amburgh, M. E., and J. Tikofsky. 2001. The advantages of "accelerated growth" in heifer rearing. Adv. Dairy Technol. 13:79-97. van Straten, M., N. Y. Shpigel, and M. Friger. 2008. Analysis of daily body weight of high-producing dairy cows in the first one hundred twenty days of lactation and associations with ovarian inactivity. J. Dairy Sci. 91:3353-3362. https://doi.org/10.3168/jds.2008 -1020 .

Weller, M. M. D. C. A., R. L. Albino, M. I. Marcondes, W. Silva, K. M. Daniels, M. M. Campos, M. S. Duarte, M. L. Mescouto, F. F. Silva, and S. E. F. Guimarães. 2016. Effects of nutrient intake level on mammary parenchyma growth and gene expression in crossbred (Holstein $\times$ Gyr) prepubertal heifers. J. Dairy Sci. 99:9962-9973. https://doi.org/10.3168/jds.2016-11532.

Williams, E. J., H. Gilmore, F. Carter, M. A. Crowe, A. Evans, P. Lonergan, M. Diskin, C. Ferris, F. Young, and R. Law. 2009. Live weight at calving as a predictor of postpartum energy status and uterine infection in dairy cows. Reprod. Domest. Anim. 44:131.

Zanton, G. I., and A. J. Heinrichs. 2005. Meta-analysis to assess effect of prepubertal average daily gain on Holstein heifers on first lactation production. J. Dairy Sci. 88:3860-3867. https://doi.org/ 10.3168/jds.S0022-0302(05)73071-X. 